\title{
Associative Dictionaries as an Ethnic Mental \\ Phenomenon: Basic Values in the Core of Ethnic Group Language Consciousness
}

\section{Ассоциативные словари как этноментальный феномен: базовые ценности \\ в ядре языкового сознания этноса}

\author{
Natalya Dmitryuk ${ }^{1,2}$ \\ Dr. Sc. in Philology, \\ Professor
}

\author{
Наталья Дмитрюк ${ }^{1,2}$ \\ доктор филологических наук, \\ профессор
}

E-mail: nvdmitr@yandex.ru https://orcid.org/0000-0002-8527-0338

Galina Abramova ${ }^{1}$

$\mathrm{Ph}$. D. in Linguistics,

Assistant Professor
Галина Абрамова ${ }^{1}$

кандидат филологических наук, доцент

E-mail: nishgalina@mail.ru

https://orcid.org/0000-0001-7105-918X

${ }^{1}$ South-Kazakhstan State Pedagogical

University (Kazakhstan)

13, Bajtursynov Str., Shymkent, Kazakhstan, 160012

${ }^{2}$ South Ural State University

(Russian Federation)

$\triangle 76$, Lenin Str.,

Chelyabinsk, 454080
${ }^{1}$ Южно-Казахстанский государственный педагогический университет (Казахстан)

$\triangle$ ул. Байтурсынова, 13, Шымкент,

Казахстан, 160012

${ }^{2}$ Южно-Уральский

государственньий университет (Россия)

$\triangle$ ул. Ленина, 76, Челябинск, 454080

Original manuscript received January 27, 2021

Revised manuscript accepted October 07, 2021 


\begin{abstract}
Introduction. Associative research is widely practiced in the field of sciences related to linguistics as an interdisciplinary approach to the study of the relationship of language with consciousness, psyche, and human culture; the corpus of associative data we have created in the Kazakh language replenishes associative lexicography in the context of broad intercultural comparisons.
\end{abstract}

Materials and methods. The dictionaries of the associative norms of the Kazakh language (Dmitryuk, 1978; Dmitryuk, Moldalieva et al., 2014), prepared on the basis of data of free associative experiments (SAE) with 1000 Kazakh students, contain unique information about the mentality and ethnocultural characteristics of the Kazakh ethnic group in the Soviet and modern period.

FAE is a well-known method of employing the associative experiment data, the reliable way to access a person's linguistic consciousness; statistical processing of the FAE body associative data provided for the analytical comparison of a hierarchical sequence of the Kazakh basic values as a linguistic consciousness core - its central and peripheral zones - in the Soviet and post-Soviet periods.

Results. Due to the diachronic and interethnic comparative analysis: such basic Kazakh values as religion beliefs, freedom, sovereignty, state symbols have been subjected to the significant changes; ethnic cultural kernel preferences remained traditionally unchanged, constituting the specific essence of the ethnic national mentality: attitude to motherland, mother, elders, men, gender and age as specific peculiarities in the hierarchy of family relations.

Conclusions. The intralingua comparison of the dictionaries' contents revealed a very stable body of unchanging value priorities, indicating a fairly strong core and a significant vitality degree of Kazakh society.

The work contributes to the intercultural associative research, associative lexicography and provides for the development of promising research in Psycholinguistics in Kazakhstan.

Key words: Kazakh associative dictionaries, core of language consciousness, basic values.

\title{
Introduction
}

\section{History of Association Studies}

Associative direction in the study of speech activity - acting speech process and speech perception, mechanisms of its management, the organization of lexicon and storage of vocabulary in human memory, and others - has a long research history, represented by well-known followers and schools, providing a great theoretical and methodological base and reliable experimental grounds for further research, later driven by the challenges of the $21^{\text {st }}$ century. 
Separate from ancient theories of knowledge (such as those of Aristotle, Plato, and Democritus, who used the term association in connection with the mental processes of memory, recall, reflection of reality), the lingual psychological experiences of psychiatrists, psychologists, and linguists of early and mid-twentieth century can be considered the starting point of modern associative experimental studies in the beginning and middle of the $20^{\text {th }}$ century. The great Enlightenment thinkers B. Spinoza (1957), R. Descartes (Descartes, 1989), and others defined the association as some features of the "movement of thoughts"; their followers Locke (1985), Berkeley (1978), and Hume (1998) contributed to the creation of "associative psychology", where associations act as the "connective tissue" between images of consciousness ("bundles of ideas" according to Locke) and objects of the external world in the line of subjective idealism.

Further linguophilosophical and psychological studies contributed to the creation of the associative research methods in psychology, psychiatry, and neuropsychology at the beginning of the $20^{\text {th }}$ century and its advancement in America and Europe, and later in Russia, which largely contributed to the emergence of a new branch of knowledge Psycholinguistics. The famous psychologists C.G. Jung (1919), G.H. Kent and A.J. Rosanoff (2006), L.S. Vygotsky (1996), A.R. Luria (2013), and others successfully made use of a variety of highly original and witty techniques and methods of employing the "association" for experimental purposes of testing and proving new ideas and hypotheses in psychology and psychiatry.

Much later, the works of Wilhelm von Humboldt (Humboldt, 1999) demonstrated a scientific interest in the linguistic component of associative research, compared to psychology and philosophy, which can be considered a precursor to the formation of integrative scientific knowledge by creating new vectors for joint research in linguistics (language and thought $\rightarrow$ Cognitive Linguistics), linguistics and psychology (language and linguistics $\rightarrow$ language consciousness $\rightarrow$ Psycholinguistics), linguistics and ethnology (language and "spirit of the people" $\rightarrow$ Ethnolinguistics, language and culture $\rightarrow$ Cultural Linguistics), and others. Analyzing the dialectics of subjective and objective in the language, von Humboldt observes that understanding between people is possible only because everyone "has flashes of 
meanings in his mind which are relevant, but not identical," i.e. associations (Humboldt, 1984: 166).

In his seminal essay, Thought and Language, the founder of psychology in Russia Alexander Potenbnya substantiated the idea of a word as a form of thought, highlighting the internal form of the word as "the relation of the content of thought to consciousness" (Potebnya, 1999). The founder of the Kazan school of linguistics Jan Boduen de Courtenay (2017) and his followers, who distinguished associations in terms of similarity and adjacency, distinguished between the paradigmatic and syntagmatic associative organization of lexis and divided the associations into direct linguistic and indirect extralinguistic ones.

\section{The Concept of our Theoretical Research}

The concept of our theoretical research is based on the representation of the structure of linguistic consciousness and the theory of speech activity by A.A. Leontyev, where language is invariably understood as a reflection of sociocultural reality (Leontyev, 1993: 16-21). The process of verbal reflection of a person's interaction with the world is presented in linguistic consciousness (LC) in the form of an associative-verbal network (AVN) in the materials of associative dictionaries, fixing the hierarchy of basic values of an ethnic group the core of linguistic consciousness. The value of AVD is also due to the fact that it allows one to carry out a diachronic analysis of the living dynamics of the nuclear system within several generations, as we have shown comparing the content of two Kazakh associative dictionaries KRAD (1978) and KAD (2014) when revealing not only a change and transformation of value priorities, but also the presence of invariable ethnocultural basic values of the Kazakh ethnos.

\section{Methods and Techniques of the Research}

The twentieth century was marked by the rapid development of the natural sciences and the humanities, at the junction of which peculiar "growth points" began to appear - new discoveries made by the joint efforts of scientists from related sciences. The integration of sciences has spawned new branches of humanitarian knowledge, including 
psycholinguistics, ethnopsychology, linguoculturology, sociolinguistics, and mentalinguistics.

Currently, the growing interest in the nature of the relationship between language and thinking, language and consciousness, language and culture is also associated with a change in the socio-political situation in the world. Expanding contacts among countries, cultures, and people, respectively, are creating a new, "multicolored" world with a diversity of viewpoints, values, and priorities. This general phenomenon was clearly articulated by E.F. Tarasov in his theory of intercultural communication (Tarasov, 1996, 1998). According to Tarasov, the main cause of misunderstanding in intercultural communication is explained not so much by the difference between languages but as a mismatch in the national consciousness of communicants (Tarasov, 1998: 30). This opinion is quite common and well developed in the scientific literature: as Vygotsky mentions, the actual process of intercultural communication takes place only in the form of "communication of consciousness" (Vygotsky, 1999) whereas, according to Bakhtin, the dialogue of cultures is not so much a communication of different consciousness but

"rather as a communication of images of different cultures within the framework of a single consciousness" (Bakhtin, 1986:16).

In this context, it becomes relevant to address issues about the structure, content, and forms by which the consciousness and the mental vocabulary of a person functions, i.e. the creation of a theory of consciousness and methods for its study. Generally speaking, these research objectives united the commitment of scientists from related branches who were striving to establish principles for a general theory of consciousness and its verification through experimental, in particular associative, methods. So for the first time in the study of language and consciousness, scientists came to the poly semantic and widely discussed term "linguistic consciousness".

We accept Leontiev's definition of linguistic consciousness as fundamental, as the founder of Russian psycholinguistics:

"If we understand language as the unity of communication and generalization, as a system of meanings, acting both in the objective and in the verbal form of existence, then the 'linguistic consciousness,' the consciousness considered as mediated by meanings, turns out to be close to the understanding that modern Soviet psychology puts 
into the concept of image of the world. ... I consider it necessary to emphasize that this concept is by no means identical either to the concept of 'linguistic picture' of the world or to the concept of 'cognitive picture' of the world" (Leontiev, 1993: 18).

A special contribution to the development of the theory of consciousness and the organization of the person's internal vocabulary was made by the Tver Psycholinguistic School led by A.A. Zalevskaya (1980, 2007). Developing a theory of word meaning, Zalevskaya suggests taking an associative approach as a leading trend in the description of meaning. The definition of a word's associative meaning is, as many modern studies show, very promising in identifying ethno specific stereotypes of behavior, basic values of a person and their hierarchy in the linguistic consciousness of an individual and ethnos. We will now consider the essence and purpose of associative methods in psycholinguistic research.

\section{The Free Associative Experiment as the Principle Research Method of the Language Consciousness}

One of the most accessible and reliable methods of studying linguistic consciousness today is the free associative experiment (FAE), which presents clearly and consistently the content and functioning of different layers of linguistic consciousness, the hierarchy of value ideas about the world, and the existing relationships between words and the concepts reflected in them. FAE sheds light on human linguistic consciousness and subjective-intuitive world outlook, which is not usually perceived by the native speakers and is not revealed by other research methods.

An associative experiment (AE) is a psychological tool aimed at identifying associations that an individual has developed in his previous experience. Associations can be verbal and nonverbal - subject, color, musical, odor, taste, etc. The associative experiment method has been widely used in psychology; it later proved to be a reliable tool in psycholinguistics, for example, to explore the psychological, categorical, and substantive meaning of words (as practiced by Postman, 1970; Russel \& Jenkins, 1954; Vygotsky, 1996; Leontiev, 1993; Zalevskaya, 2007, et al.). AE offers a means to study images of consciousness, which are "made external" (as per Tarasov) by verbal associations 
(Tarasov, 1998; Goroshko, 2001; Ufimtseva, 2020; Balyasnikova, Dmitryuk \& Ufimtseva, 2020, et al.), and is also of great assistance in cross-linguistic and cross-cultural studies in Russia and Kazakhstan (as per Zalevskaya, 1971, 1980; Cherkasova, 2005; Dmitryuk, 2012; Abramova, 2006; Gizdatov, 1997, and others).

Initially, association experiments were conducted by foreign psychologists and psychiatrists to examine the processes of perception, recollection, formation of concepts, generalizations, and other trends (as per Jung, 1919; Russell \& Jenkins, 1954, and others).

Linguists borrowed free associative experiment (FAE) methodology from K. Jung's (1919), psychiatric research, currently this method is one of the simplest and the most effective ways to study linguistic consciousness. In this methodology, a large number of respondents (from 500 to 1000 or more) are offered to respond to word-stimuli (S) with the first associations that come to mind, known as the associative reactions (R). Psychologists created the first dictionaries of associative norms that helped the psychiatrists to establish "normality" or "abnormality" of the patient's mental health. This technique was adopted and used by the psycholinguists.

\section{Dictionaries of the Associative Norms}

The "Minnesota Norms" published by W.A. Russell and J.J. Jenkins (1954) was the first widely known dictionary of associative norms in English providing the background for many similar studies.

"Word Association Norms," edited by L. Postman, is of great interest to many researchers, as it includes almost all the associative norms collected earlier in English, French, and German (Postman, 1970). The lists of stimulus words are mainly based on a list of one hundred words by G. Kent and A. Rozanoff (2006), the methodology, conditions for conducting FAE, and the number of informants is also traditional.

Another publication, "Associative Thesaurus of the English Language" (Kiss et al., 1972) is widely popular with linguists, psychologists, and cultural scientists. It includes not only data on "direct" associative relationships (i.e. from stimulus $\mathrm{S}$ to reaction $\mathrm{R}$ ), but also the data on "feedback" links (i.e. all words that triggered the same word as a response). The method of "joining" the associative verbal network, the nature of the results and the possibility of using this thesaurus for different purposes were discussed in detail by Zalevskaya (2007). 
The theory of meaning was widely discussed among foreign linguists in the last century due to the great psycholinguists' interests in association studies. Among the more problematic issues discussed were the associative meaning of the word, and the organization of the human lexicon. Associations in this regard are considered a means of access to the internal human vocabulary (or to linguistic consciousness); they also may serve as a means of forming the hierarchy of the human core values and the ethnos as a whole - i.e. the core language consciousness (according to the terminology of the Moscow Psycholinguistic school) or the core mental lexicon (according to the terminology of the Tver Psycholinguistic school).

The second half of the $20^{\text {th }}$ century was distinguished by widespread work in experimental association research, resulting in the creation of a series of associative dictionaries (using the KentRosanoff list of stimuli): German, French, and Italian (Rosenzweig, 1961), Russian (Leontiev, 1977), Bulgarian (Gerganov, 1984), Ukrainian (Butenko, 1979; Martinek, 2007, 2008), Byelorussian (Tsitova, 1981), Latvian (Ulyanov, 1988), Kirgiz (Titova, 1975), Kazakh (Dmitryuk, 1978), and other languages. In particular we should mention the Ukrainian Associative Dictionary by S. Martinek (2007, 2008), in which

"for the first time in associative lexicographic practice, the reactions of male and female respondents are presented separately, which makes it possible to use its materials for gender studies; in general, the materials of the dictionary help to reveal the culturally specific features of the conceptual picture of the world, embodied in the Ukrainian language" (Martinek, 2007).

An extensive bibliography of associative studies is presented in the work of E.I. Goroshko, and provides for systematization and classification of existing associative dictionaries, highlights the applied aspects of associative lexicography, describes in detail the model of the associative thesaurus as a powerful tool in social research, while the associative-verbal network of the thesaurus is thought of as another way of representing language, correlated with the linguistic ability of its speaker (Goroshko 2001: 158-197).

The associative experiments is also successfully used for didactic purposes: in the process of learning to master vocabulary (Baydak et al., 2015; Bekova, 2013), for exploring the memory associative structure 
in the perception and interpretation of the unknown foreign words, and to study the problems of bilingualism (Lubimova, 2020; Mukhametzyanova \& Shayakhmetova, 2014; Kheirzadeh \& Hajiabed, 2016), to study the sociocultural stereotypes and the specifics of the linguistic consciousness (Raible, 2003; Izbasarov et al., 2017; Sharifian, 2017), to study the mechanisms of speech perception in the paradigm of activity psycholinguistics (Kharchenko, 2017).

By now, a solid methodological basis for the study of associations has already been formed, the main classical provisions of the theory of associations have been identified, various classifications of types of associations have been created depending on the principles and different bases of their analysis, etc.

\section{Adherence to Ethical Standards}

The article was ethically approved at a meeting of the Council of the Philological Faculty of the South Kazakhstan State Pedagogical University.

For conduct of this research no funds, grants or other support was received.

The authors do not have any financial or property interests concerning the materials presented in this article.

\section{Results}

\section{Association studies in Kazakhstan}

In Kazakhstan, the first associative linguistic experiments with native speakers of Russian and Kazakh languages were carried out in the 1960s and 1970s by A.A. Zalevskaya (1971, 1980), and M.M. Kopylenko (1995). They were introduced into the sphere of broad interlinguistic comparisons and shown capable of such tasks as identifying the socio-cultural influences in perception, mapping linguistic images of the world, modeling verbal memory, displaying the center and periphery of the inner lexicon, and classing the mental and lingua cultural "climate" of a particular society.

Further associative researches based on the materials of the Kazakh and Russian languages in Kazakhstan linguistics were initiated by N.V. Dmitryuk (1978, 2012) and others, and G.G. Gizdatov (1997). 
Associative psycholinguistic experiments based on associative techniques gained momentum in Kazakhstan at the beginning of the $21^{\text {st }}$ century, proving useful in addressing issues of socio cultural identification and communication.

\section{Kazakh Associative Dictionaries}

Currently, the object of the research in the article is a content study of two associative dictionaries of the Kazakh language: The Kazakh-Russian Associative Dictionary - KRAD-1978 (Dmitryuk, 1978) and Kazakh Associative Dictionary - KAD-2014 (Dmitryuk, Moldaliyeva et al., 2014) in a comparative aspect. A short information about the dictionary is given below.

The Kazakh-Russian Associative Dictionary (KRAD-1978) published information derived from FAEs conducted in 1975-1976. In these FAEs, questionnaires were given to the native Kazakh students from different universities in Shymkent, Kazakhstan, approximately 1000 respondents. The word-stimuli list in the questionnaire was based on Kent and Rosanoff's word list, which was an accepted international practice for FAE and later translated into Kazakh.

Compiled in accordance with the generally accepted international practice requirements for the conduct of FAE, KRAD-1978 is a fairly objective picture of the linguistic consciousness of the "average" native Kazakh language speaker in the last decades of the Soviet period, it has translations of stimuli and reaction-associations into the Russian language for the convenience of using it. KRAD-1978

"expands the possibilities of cross-language comparative analysis of verbal associations, which are considered as models of speech knowledge native speakers and reflect not only semantic and grammatical relationships within the language, but also are a fragment of the images of consciousness, human verbal memory" (Dmitryuk, 1978: 5-27).

A detailed description of the methodology for conducting the SAE, the choice of subjects, the problems of translating stimulus words and responses into the Kazakh language and the construction of a dictionary entry in KRAS-1978 is presented in the Preface to the dictionary.

The second Қазақша ассоциациялық сөздік / Kazakh Associative Dictionary (KAD-2014) was based on a series of FAEs conducted 
in 2012-2013, again using Kazakh students from South Kazakhstan. Over 1.000 respondents participated in the experiment, with an approximately equal number of male and female. This was the first time in the practice of compiling such dictionaries that gender-based systematization was used; over 120.000 male and female associative responses are presented in a tabular form on the same word-stimuli, thereby determining the language consciousness gender-specific in an individual and society as a whole.

By comparing the incentive words of the two associative Kazakh dictionaries, we see that a quarter of the list of words of the related questionnaires coincide with one another. This is important for comparing differences in perception of meanings and concepts among ethnic groups; for example, it is noteworthy to compare concepts marked and unmarked by ethnic, social, gender and other parameters to identify both the differences and commonalities of their perceptions and understanding. At the same time, similar incentive words in the FAE questionnaires are not required to determine world image consistency among different ethnic groups in order to reveal the central, most meaningful, and peripheral zones of lexical formation. According to N. Ufimtseva, this factor is of no particular importance for identifying the core of linguistic consciousness:

"...Comparing the Russian sections...of the Slavic Associative Dictionary with the Russian Associative Dictionary, we can see that only seven of 30 words are not included in the 'big core' of Russian linguistic consciousness. This once again confirms what was noted when analyzing the Russian Associative Dictionary: that any sufficiently large list of stimulus words (at least 50) leads to the same core of linguistic consciousness for each given culture, i.e. to the concepts central to a given image of the world in their relation to each other, i.e. in their consistency. One may assume that the systematic nature and content of the core linguistic consciousness reflect the systematic nature and content of ethnic constants existing in the collective unconscious" (Ufimtseva, 2000: 217).

The data of both Kazakh associative dictionaries thus match those of similar studies, which opens the door to wider cross-language and cross-cultural comparisons. For this purpose, the authors have translated the KADs into Russian (though with the caveat that translation is not an exact science). The two dictionaries provide unique insight into how 
two generations of Kazakh youth perceive their world within a specific socio-cultural context. The dictionaries can thus serve as a tool of ethno-linguistic, cultural, and socio-psychological studies of the mental environment of two generations of native Kazakh speakers.

The objective of our ethnic psycholinguistic and socio-cultural research is a diachronic analysis of native Kazakh speakers during the Soviet period and in the present day. As the subject of study we examined features of transformation of basic values in the linguistic consciousness of the respondents. The associated reactions of the two generations of Kazakhs, presented in the form of an associative-verbal network (AVN) in direct dictionaries (from stimulus to reaction) served as a basis for distinguishing inverse dictionaries (from reactions to the stimulus) for determining central values - basic values that make up the core of the language consciousness of native Kazakh speakers as a dynamic process in the evolutionary development of their culture and civilization. Having created the core of linguistic consciousness, our goal was

"to identify the hierarchy of basic values of the Kazakh ethnic group and their transformation, to determine the direction and degree of displacement of the main strategies for associative behavior among experiment respondents, and the change in the mental climate and axiological reflections in the linguistic consciousness of native Kazakh speakers in the Soviet and post-socialist/modern period" (Dmitryuk, Artykbaeva \& Cherkasova, 2016: 140).

\section{The Core of Linguistic Consciousness}

The core concept in linguistics, as borrowed from the natural sciences, has long acquired the status of a particular "center," as opposed to the periphery in the hierarchy of compared gradual phenomena. Examples would include the lexical and statistical core of the dictionary, the core of the general vocabulary of related languages, the core of the active vocabulary of the national language, among others. Traditionally, in the psycholinguistic research using FAE and similar techniques, the core concept acquires a specific meaning. In these cases, the core is considered the most frequently reproduced association-reaction $(\mathrm{R})$ in response to the stimulus words $(\mathrm{S})$ proposed in the experiment. At the same time, there are different methods for compiling such a core: with 
the advent of computer technology and digital capabilities for processing associative materials, new ways of identifying response frequency began to emerge.

New statistical methods appeared for calculating not only the direct nature of association (from stimulus to reaction: $S \rightarrow R$ ), but also the inverse one (from reaction to stimulus: $R \rightarrow S$ ), which made it possible to determine the mutual attraction of stimuli and reactions. This makes some sense - the greater the number of stimuli generating identical reactions, the greater number of connections revealed in the associativeverbal network (AVN), that is why some researchers build the core according to the number of the stimuli generated (i.e. connections) without taking into account the frequency of response associations. Response frequency cannot be ignored, however, so there is another option to build the core using the maximum response frequency by the same word-association within the entire AVN. In our studies of the Soviet period (Dmitryuk, 1978), we also made an attempt to identify the core words - the first 10 and 30 most common high-frequency words (associations and stimuli) - by computer-based statistical processing in the entire body of association reactions in the direct dictionary KRAD-1978.

\section{Intraethnic Diachronic Study of the Kazakh Language Consciousness}

Along with the generally accepted comparative studies of intercultural and inter-ethnic nature in psycholinguistics, we must mention the heuristic and promising aspects of the intra-ethnic research of the linguistic consciousness, which are of certain interest, because a comparison of the ethnic group with itself is observed in a diachronic aspect - Kazakhs are compared with Kazakhs, and Russians - with Russians in different time periods; i.e. when the ethnic linguistic consciousness and mentality transformations is intuitively recognized but it demands the thorough scientific justification.

Such studies have recently become widely popular in the European and Russian psycholinguistics, where free association experiments were conducted long before and the dictionaries of association norms of different languages have been created on their basis. For example, at present, five associative dictionaries of the Russian language of different 
periods have already been created, and Russian scientists have the opportunity to compare on their basis how much the value orientations and the mental climate of the Russian ethnos have changed in different eras. As far as the Kazakh mentality presented in the prism of association studies is concerned, there also is a unique opportunity of the similar intra-ethnic diachronic comparison based on the two mentioned Kazakh associative dictionaries of Soviet and modern period. To expand the viewing area of the studied conceptual values, their hierarchy and analysis of the specific content we turn to the comparison of the content of 'big' core of the Kazakh language consciousness, compiled on the material of direct and inverse Kazakh association dictionaries of the Soviet and modern period.

The representativeness of the dynamics of the Kazakhs language consciousness in the Soviet and modern period we shall demonstrate on the example of the 'big' core of the language consciousness based on KRAD-1978 and KAD-2014 materials; they include the first 100 words, recorded in the active associative speech body of widely popular vocabulary of the Kazakh language, functioning in the language consciousness of two generations of the titular ethnos of Kazakhstan in different periods (Tabl. 1, 2).

\section{Table 1}

CORE of Kazakh language consciousness (the first 100 words of incentives) (According to N.V. Dmitryuk Kazakh-Russian Associative Dictionary KRAD-1978)

\begin{tabular}{|l|l|c|c|}
\hline Rank & \multicolumn{1}{|c|}{ Associate } & $\boldsymbol{S}$ & $\boldsymbol{R}$ \\
\hline 1. & Адам (human) & 70 & 1299 \\
\hline 2. & Әдемі (beautiful) & 70 & 1033 \\
\hline 3. & Өмір (life) & 58 & 1040 \\
\hline 4. & Үлкен (big) & 54 & 506 \\
\hline 5. & Жақсы (good) & 52 & 371 \\
\hline 6. & Ана (mother) & 48 & 347 \\
\hline 7. & Бала (child) & 47 & 312 \\
\hline 8. & Ақ (white) & 46 & 423 \\
\hline 9. & Көп (many) & 43 & 640 \\
\hline 10. & Жер (earth) & 42 & 639 \\
\hline 11. & Керек (needed) & 42 & 375 \\
\hline 12. & Үй (house) & 42 & 320 \\
\hline 13. & Жоқ (no) & 39 & 121 \\
\hline 14. & Қара (black) & 37 & 362 \\
\hline 15. & Болу (to be) & 34 & 347 \\
\hline
\end{tabular}

\begin{tabular}{|l|l|c|c|}
\hline Rank & \multicolumn{1}{|c|}{ Associate } & \multicolumn{1}{c|}{$\boldsymbol{S}$} & $\boldsymbol{R}$ \\
\hline 51. & Сары (yellow) & 24 & 305 \\
\hline 52. & Кішкентай (small) & 24 & 205 \\
\hline 53. & Ұзақ (far) & 24 & 185 \\
\hline 54. & Қуаныш (joyfulness) & 24 & 182 \\
\hline 55. & Жұмыс (work) & 24 & 154 \\
\hline 56. & Парта (desk) & 24 & 123 \\
\hline 57. & Мұғалім (teacher) & 24 & 75 \\
\hline 58. & Жарық (light) & 23 & 301 \\
\hline 59. & Арман (dream) & 23 & 285 \\
\hline 60. & Ұзын (long) & 23 & 283 \\
\hline 61. & Кісі (man) & 23 & 244 \\
\hline 62. & Қиын (difficult) & 23 & 190 \\
\hline 63. & Ана (mother) & 23 & 177 \\
\hline 64. & Шөп (grass) & 23 & 139 \\
\hline 65. & Ат (name; horse) & 23 & 62 \\
\hline
\end{tabular}


Associative Dictionaries as an Ethnic Mental Phenomenon...

\begin{tabular}{|l|l|c|c|}
\hline 16. & Ағаш (tree) & 34 & 298 \\
\hline 17. & Тамаша (fine) & 34 & 120 \\
\hline 18. & Келді (gone) & 33 & 358 \\
\hline 19. & Жігіт (guy) & 33 & 306 \\
\hline 20. & Қызыл (red) & 32 & 288 \\
\hline 21. & Жаман (bad) & 32 & 221 \\
\hline 22. & Қатты (strong) & 32 & 177 \\
\hline 23. & Кітап (book) & 32 & 168 \\
\hline 24. & Жас (young) & 31 & 219 \\
\hline 25. & Бақыт (happiness) & 30 & 398 \\
\hline 26. & Таза (pure) & 30 & 325 \\
\hline 27. & Қой (sheep) & 30 & 272 \\
\hline 28. & Су (wate)r & 30 & 248 \\
\hline 29. & Алу (take) & 30 & 176 \\
\hline 30. & Кино (film) & 29 & 75 \\
\hline 31. & Бар (have) & 29 & 72 \\
\hline 32. & Көйлек (dress) & 28 & 298 \\
\hline 33. & Нан (bread) & 28 & 140 \\
\hline 34. & Гүл (flower) & 27 & 300 \\
\hline 35. & Көк (white, blue) & 27 & 275 \\
\hline 36. & Дала (steppe) & 27 & 216 \\
\hline 37. & Жаңа (new) & 27 & 193 \\
\hline 38. & Машина (car) & 27 & 68 \\
\hline 39. & Түн (night) & 26 & 608 \\
\hline 40. & Зат (thing) & 26 & 124 \\
\hline 41. & Көңілді (cheerful) & 26 & 119 \\
\hline 42. & Әке (father) & 26 & 56 \\
\hline 43. & Көше (street) & 26 & 54 \\
\hline 44. & Күн (sun) & 25 & 372 \\
\hline 45. & Сұлу (beautiful) & 25 & 325 \\
\hline 46. & Ит (dog) & 25 & 197 \\
\hline 47. & Жол (road) & 25 & 145 \\
\hline 48. & Көктем (spring) & 25 & 134 \\
\hline 49. & Әсем (beautiful) & 25 & 122 \\
\hline 50. & Сағат (clock) & 25 & 44 \\
\hline
\end{tabular}

\begin{tabular}{|l|l|c|c|}
\hline 66. & Білім (knowledge) & 22 & 280 \\
\hline 67. & Тез (quickly) & 22 & 270 \\
\hline 68. & Тау (mountain) & 22 & 255 \\
\hline 69. & Жылы (warm) & 22 & 244 \\
\hline 70. & Пайдалы (useful) & 22 & 121 \\
\hline 71. & Тәтті (delicious) & 21 & 242 \\
\hline 72. & Түс (dream) & 21 & 207 \\
\hline 73. & Май (oil) & 21 & 215 \\
\hline 74. & Қысқа (short) & 21 & 93 \\
\hline 75. & Өзен (lake) & 21 & 65 \\
\hline 76. & Жаз (summer) & 21 & 56 \\
\hline 77. & Терезе (window) & 21 & 49 \\
\hline 78. & Қажет (must) & 21 & 41 \\
\hline 79. & Аспан (sky) & 20 & 496 \\
\hline 80. & Сиыр (cow) & 20 & 150 \\
\hline 81. & Кішкене (small) & 20 & 111 \\
\hline 82. & Көз (eye) & 20 & 98 \\
\hline 83. & Сүйкімді (beautiful) & 20 & 86 \\
\hline 84. & Еңбек (labor) & 20 & 78 \\
\hline 85. & Ұйықтаy (sleep) & 20 & 73 \\
\hline 86. & Жай (slowly) & 20 & 70 \\
\hline 87. & Іздеу (look for) & 20 & 48 \\
\hline 88. & Алтын (gold) & 20 & 40 \\
\hline 89. & Ақылды (clever) & 18 & 259 \\
\hline 90. & Алма (apple) & 19 & 190 \\
\hline 91. & Ой (thought) & 19 & 185 \\
\hline 92. & Қараңғы (dark) & 19 & 175 \\
\hline 93. & Ауру (disease) & 19 & 162 \\
\hline 94. & Тамақ (meal) & 19 & 151 \\
\hline 95. & Қасқыр (walf) & 19 & 136 \\
\hline 96. & Жасыл (green) & 19 & 109 \\
\hline 97. & Мысық (cat) & 19 & 100 \\
\hline 98. & Ауыл (village) & 19 & 92 \\
\hline 99. & Қоңыр (brown) & 19 & 86 \\
\hline 100. & Күз (autumn) & 19 & 26 \\
\hline & & \\
\hline
\end{tabular}

Above, we have already described the essence and method of "constructing" the core of linguistic consciousness on the basis of direct (from stimulus $-\mathrm{S}$ to response $-\mathrm{R}$ ) and reverse (from response $-\mathrm{R}$ to stimulus - S) connections in associative dictionaries. A.A. Zalevskaya (1980), and after her, N.V. Ufimtseva (2000), build the core of the lexicon (in the terminology of A.A. Zalevskaya (1980), and the core of linguistic consciousness (in the terminology of N.V. Ufimtseva (Ufimtseva \& Balyasnikova, 2019; Ufimtseva, 2020) according to the 
number of S-stimuli that generated these associations. G.A. Cherkasova (2005), consistently tracing the dynamics of changes in the number of reactions, proved the existence of "constant" and "probabilistic" responses, determining their number, at which all stimuli will be completely connected in the network. This amount turned out to be the number of $70-75$ words, which amounted to $95.0 \%$ of the array of any associative dictionary.

So, let's imagine the two cores of linguistic consciousness of the Kazakhstan ethnos in diachronic aspect in Tables 1 and 2. The first column indicates the rank of the association; the second presents the association itself with translation into Russian, and the third column shows the decreasing frequency stimulus hierarchy that caused this association, the fourth column shows the number of these reactions in the whole body of the associative dictionary.

\section{Table 2}

CORE of the Kazakh language consciousness (the first 100 words to the $S$-incentives) (According to N. Dmitryuk, G. Abramova, et al. Kazakh Associative Dictionary - KAD-2014)

\begin{tabular}{|l|l|c|c|}
\hline Rank & \multicolumn{1}{|c|}{ Associate } & \multicolumn{1}{c|}{$\boldsymbol{S}$} & $\boldsymbol{R}$ \\
\hline 1. & Жақсы (good) & 81 & 1042 \\
\hline 2. & Адам (human) & 61 & 2502 \\
\hline 3. & Әдемі (beautiful) & 60 & 1000 \\
\hline 4. & Жаман (bad) & 56 & 755 \\
\hline 5. & Көп (many) & 54 & 417 \\
\hline 6. & Бақыт (happiness) & 53 & 676 \\
\hline 7. & Өмір (life) & 53 & 628 \\
\hline 8. & Үлкен (big) & 47 & 937 \\
\hline 9. & Қуаныш (joyfulness) & 43 & 397 \\
\hline 10. & Жұмыс (labor) & 42 & 579 \\
\hline 11. & Бала (boy) & 41 & 972 \\
\hline 12. & Керек (needed) & 41 & 424 \\
\hline 13. & Жігіт (guy) & 40 & 514 \\
\hline 14. & Махаббат (love) & 40 & 398 \\
\hline 15. & Керемет (great) & 37 & 187 \\
\hline 16. & Қыз (girl) & 34 & 587 \\
\hline 17. & Ана (mother) & 33 & 602 \\
\hline 18. & Ақылды (clever) & 33 & 523 \\
\hline 19. & Жүрек (heart) & 33 & 212 \\
\hline 20. & Арман (dream) & 32 & 194 \\
\hline 21. & Отбасы (family) & 31 & 339 \\
\hline
\end{tabular}

\begin{tabular}{|l|l|c|c|}
\hline Rank & \multicolumn{1}{|c|}{ Associate } & $\boldsymbol{S}$ & $\boldsymbol{R}$ \\
\hline 51. & Су (water) & 21 & 550 \\
\hline 52. & Кішкентай (small) & 21 & 415 \\
\hline 53. & Сәби (child) & 21 & 262 \\
\hline 54. & Қара (black) & 21 & 199 \\
\hline 55. & Жарық (light) & 21 & 177 \\
\hline 56. & Ой (thought) & 21 & 111 \\
\hline 57. & Денсаулық (health) & 21 & 107 \\
\hline 58. & Күш (power) & 21 & 77 \\
\hline 59. & Бар (have) & 21 & 54 \\
\hline 60. & Тамақ (meal) & 20 & 269 \\
\hline 61. & Жол (road) & 20 & 165 \\
\hline 62. & Қала (city) & 20 & 165 \\
\hline 63. & Еркек (man) & 20 & 162 \\
\hline 64. & Киім (cloth) & 20 & 157 \\
\hline 65. & Көрікті (beautiful) & 20 & 148 \\
\hline 66. & Мама (mother) & 20 & 115 \\
\hline 67. & Кездесу (to meet) & 20 & 87 \\
\hline 68. & Ұзақ (far) & 19 & 379 \\
\hline 69. & Көлік (transport) & 19 & 256 \\
\hline 70. & Сөз (word) & 19 & 223 \\
\hline 71. & Ауру (disease) & 19 & 190 \\
\hline
\end{tabular}


Associative Dictionaries as an Ethnic Mental Phenomenon...

\begin{tabular}{|l|l|l|c|}
\hline 22. & Ақша (money) & 31 & 287 \\
\hline 23. & Таза (pure) & 30 & 427 \\
\hline 24. & Бөбек (child) & 30 & 179 \\
\hline 25. & Дос (friend) & 29 & 208 \\
\hline 26. & Үй (house) & 28 & 566 \\
\hline 27. & Жер (earth) & 28 & 412 \\
\hline 28. & Байлық (wealth) & 28 & 234 \\
\hline 29. & Күшті (strong) & 28 & 157 \\
\hline 30. & Әке (father) & 28 & 139 \\
\hline 31. & Тамаша (beautiful) & 27 & 133 \\
\hline 32. & Жас (age) & 27 & 108 \\
\hline 33. & Ел (people) & 26 & 335 \\
\hline 34. & Уақыт (time) & 26 & 159 \\
\hline 35. & Әйел (woman) & 25 & 371 \\
\hline 36. & Жақсылық (good) & 25 & 272 \\
\hline 37. & Сезім (feeling) & 25 & 246 \\
\hline 38. & Қатты (lowdly) & 24 & 199 \\
\hline 39. & Адал (honest) & 23 & 206 \\
\hline 40. & Ақ (white) & 23 & 149 \\
\hline 41. & Аз (few) & 23 & 127 \\
\hline 42. & Жоқ (no) & 23 & 116 \\
\hline 43. & Жан (soul) & 23 & 92 \\
\hline 44. & Күн (day) & 22 & 380 \\
\hline 45. & Сұлу (beautiful) & 22 & 302 \\
\hline 46. & Өмірсүру (live) & 22 & 293 \\
\hline 47. & Ағаш (tree) & 22 & 287 \\
\hline 48. & Мықты (strong) & 22 & 189 \\
\hline 49. & Күлкі (laughing) & 22 & 112 \\
\hline 50. & Әлем (world) & 22 & 104 \\
\hline & & \\
\hline
\end{tabular}

\begin{tabular}{|l|l|c|c|}
\hline 72. & Қыдыру (walk) & 19 & 148 \\
\hline 73. & Ата (grandfather) & 19 & 111 \\
\hline 74. & Халық (people, ethnos) & 19 & 110 \\
\hline 75. & Демалу (rest) & 19 & 81 \\
\hline 76. & Үміт (hope) & 19 & 80 \\
\hline 77. & Іс (affair) & 18 & 215 \\
\hline 78. & Мәңгілік (eternity) & 18 & 195 \\
\hline 79. & Өлім (death) & 18 & 183 \\
\hline 80. & Жамандық (evil) & 18 & 144 \\
\hline 81. & Кісі (human) & 18 & 112 \\
\hline 82. & Көңілді (cheerful) & 18 & 96 \\
\hline 83. & Оку (study) & 18 & 64 \\
\hline 84. & Ата-ана (parents) & 17 & 247 \\
\hline 85. & Жанұя (family) & 17 & 197 \\
\hline 86. & Жүру (go) & 17 & 188 \\
\hline 87. & Гүл (flower) & 17 & 176 \\
\hline 88. & Әңгіме (conversation) & 17 & 175 \\
\hline 89. & Тез (quickly) & 17 & 166 \\
\hline 90. & Отан (motherland) & 17 & 165 \\
\hline 91. & Нәзік (gentle, tender) & 17 & 163 \\
\hline 92. & Зат (thing) & 17 & 152 \\
\hline 93. & Ауыл (village) & 17 & 132 \\
\hline 94. & Көз (eyes) & 17 & 124 \\
\hline 95. & Іздеу (look for) & 17 & 111 \\
\hline 96. & Тіршілік (movement) & 17 & 110 \\
\hline 97. & Мен (I) & 17 & 90 \\
\hline 98. & Арам (cowardly, vile) & 17 & 85 \\
\hline 99. & Кітап (book) & 17 & 80 \\
\hline 100. & Жағымды (pleasant) & 17 & 73 \\
\hline & & & \\
\hline
\end{tabular}

As we noted above, one can also structure the core according to the frequency of reactions by interchanging the $4(\mathrm{R})$ and $3(\mathrm{~S})$ columns: at the same time, by arranging the reactions in decreasing frequency, we can make sure that the rank of some associations will change, but in general the main composition of the associates will remain unchanged both in the small (30 words) and the large core of consciousness (75100 words). With this approach, in the conceptual center (the first 10 words) in the Kazakh core of consciousness, 7 of the significant values presented in tables will remain: adam (man), ylken (big), jaksy (good), ақ (white), әdemi (beautiful), бала (child), kөn (many); instead of өмір (life), ана (mother), жер (earth), which will go down to the 12th, 19th and 23rd places, there aspan (sky), bakyt (happiness), kerek (necessary) 
will appear. Therefore, we join the opinion of researchers who believe that there is no big and fundamental difference in the formation of the core according to the frequency of reactions decreasing or to the frequency of stimuli that caused these reactions.

\section{Discussions}

Different scientific opinions exist about the choice of methodology, objectives, and core design. The mental lexicon core was first identified by A.A. Zalevskaya based on Kiss' English Associative Dictionary (Kiss et al., 1972) in connection with her proposed concept of the word as a means of access to a single human information base (Zalevskaya, 1971, 1980).

The trend emerged of highlighting the active core in the organization of the human mental lexicon in associative studies and was productively used in a variety of ways - examples include identifying the national and cultural identity and systematic characteristics of linguistic consciousness images (Ufimtseva \& Balyasnikova, 2019; Ufimtseva, 2020; Balyasnikova, Dmitryuk \& Ufimtseva, 2020), establishing the semantic dominant of the linguistic personality of the child (Sokolova, 1999), studying the features of preschoolers' and primary school students' images of the world (Ovchinnikova et al., 2000), Kazakhs, Russians and English (Abramova, 2006) and determining the characteristics of verbal behavior in professional communication (Kharchenko, 2003), and in the intercultural communication (Balyasnikova et al., 2018; Dmitryuk \& Balyasnikova, 2020) et al.

In one form or another, researchers strove to identify the most relevant core of the associative-verbal net-work, which could include a certain number (10 to 100) units that differ in degree of "attraction" to the high-frequency center - from the most active (10 words, which is the "conceptual center" of core linguistic consciousness") to the least active (30 words, considered the "small" core) and, further approaching the periphery, an arbitrary number of associates from 75 to 100 units, which is considered to be a "large" core of linguistic consciousness.

* For comparison, we present the Laurent List, well known to specialists in general semantics, which names ten values that form a kind of system of rods on which the consciousness of the individual and society rests: God, Motherland, banner, duty, honor, friendship, tenderness, death, life, hope. 
In addition, a simple comparison of the lists of words included in the core of linguistic consciousness is uninformative. The coincidence of the words-correlates in different linguistic cultures and even their equally high rank in the core of consciousness do not ensure complete coincidence or closeness of ideas about the named subject. Representatives of different ethnic groups and generations can have completely different Ideas of friend and friendship, home and family, of homeland and duty, even if these conceptually significant units of the mental lexicon were found in the central zone of the core of linguistic consciousness.

"Two words in two different languages, denoting the same object in the cultures of the two peoples and being translated equivalents, inevitably turn out to be non-identical in content, enriched with a kind of associations conditioned by national culture, specific images of consciousness" (Dmitryuk, 2012: 83).

Presenting the material in the Tables we demonstrate some similarities and differences in the content of the mental lexicon of the Kazakh ethnic group in different historical periods of its life, we will leave to the reader the possibility and the right to self-reflection on the specific hierarchy of values defined in the core language consciousness of two generations of Kazakhs. We can assume that basic values such as attitude to religion, freedom, sovereignty, to national symbols, and so have undergone predictable changes in consciousness and mentality of the Kazakh ethnic group during the post-socialist period.

However, in our opinion, certain value preferences, ethno cultural core values, rules of behavior, not subjected to time change and contributing to the preservation of the viability and vitality of society can and must exist. Tradition and permanence of certain ethno cultural basic elements that make up the essence of the specific features of the national character and ethnos mentality: the attitude to the homeland and to one's mother, to seniors, to a man, the gender and age characteristics in the hierarchy of family and kinship relations, etc. possibly may be predictably immutable. However, we will define this topic for ourselves as an object of a separate study and take it beyond the scope of this article. 


\section{Conclusions}

(1). The original material obtained in the field experimental research with the native Kazakh culture bearers expands the range of cross-language and intercultural comparisons and replenishes a body of the associative data for the different world languages.

(2). The free associative experiment, recognized by the international scientific community as the primary means of an access to the linguistic consciousness occupies in our research the central place and it provides for the quite reliable and valid results of the field experimental research.

(3). Kazakh association dictionaries (KRAD-1978 and KAD-2014) compiled on the original material of associative experiments carried out in the Soviet period and nowadays are of the scientific interest, as they reflect the image of the Kazakh verbalized fragments of consciousness and can be used to study the national cultural specificity of mentality and worldview by the representatives of two generations of the Kazakh nation, including the context of the broad cross-language comparisons.

(4). The study of the content and the transformation of ethnic mental basic values which are structured in the ethnic language consciousness core in a certain hierarchical sequence as the most significant, is of great interest, especially in our epoch when a trend of substitution of traditional national values by various types of universal and other benefits of civilization is manifested.

(5). In our opinion the associative direction can become very promising in Kazakhstan's psycholinguistics, which will be associated, firstly, with the identification of the area of coincidence of associative reactions - the determination of ethnic constants, a certain unchanging rod in the collective consciousness of an ethnic group over a certain period of time; secondly, with the fixation of a certain area of change the transformation and reformation of the linguistic consciousness of the titular ethnic group of Kazakhstan in the post-Soviet, post-reform and modern periods, which, of course, is not only of linguistic interest, but is also associated with the study of a wide range of social, ethno cultural and political issues of our time. 


\section{References}

Abramova, G.I. (2006). Psiholingvisticheskie aspekty izucheniya yazykovogo soznaniya [Psycholinguistic aspects of the language consciousness study]. Bulletin of Karaganda University. Philology series, 2(42), 33-36 [in Russian].

Bakhtin, M.M. (1986). Literaturno-kriticheskie stati [Literary-Critical Articles]. (Vols. 1-2). Moscow : Fiction [in Russian].

Balyasnikova, O.V., Dmitryuk, N.V., \& Ufimtseva, N.V. (2020). Potencialno konflitogenniye zony $\mathrm{v}$ yazikovom soznanii dvuyazichnih [Potentially Conflictogenic Zones in the Language Consciousness of Bilinguals]. Philological Sciences. Scientific Reports of the Higher School, 6(2), 163-170. https://doi. org/10.20339/PhS.6-20.163 [in Russian].

Balyasnikova, O.V., Ufimtseva, N.V., Cherkasova, G.A., \& Chulkina, N.L. (2018). Lingvistika i kogniciya : regionalnye perspektivy [Language and Cognition : Regional Perspective]. Russian Journal of Linguistics, 22(2), 232-250. https:// doi.org/10.22363/2312-9182-2018-22-2-232-250 [in Russian].

Baudouin de Courtenay, I.A. (2017). Izbrannye trudy po obshchemu yazykoznaniyu [Selected Works on General Linguistics]. Moscow : Academy of Sciences [in Russian].

Baydak, A., Scharioth, C., \& Ilyashenko, I. (2015). Interaction of Language and Culture in the Process of International Education. Procedia - Social and Behavioral Sciences, 215(2015), 14-18. https://doi.org/10.1016/j.sbspro.2015.11.567

Bekova, Z.K. (2013). Ethnic Picture of the World and Its Influence upon the Process of Adaptation in Higher Education al Establishments. Procedia Social and Behavioral Sciences, 114(2014), 939-943. https://doi.org/10.1016/j. sbspro.2013.12.811

Berkeley, D. (1978). Sochinenija [Works]. In S. Narsky (Ed.). Moscow : Mysl [in Russian].

Butenko, N.P. (1979). Slovnik associativnyh norm ukrainskoj movi [Dictionary of Associative Ukrainian Standards]. (Vols. 1-2). Lviv [in Ukrainian].

Cherkasova, G.A. (2005). Kvantitativnye issledovaniya associativnyh slovarej [Quatitative Study of Associative Dictionaries]. Obshhenie. Jazykovoe soznanie. Mezhkulturnaja kommunikacija - Communication. Language Consciousness. Intercultural Communication (pp. 227-244). Kaluga [in Russian].

Descartes, R. (1989). Sochinenija [Works]. (Vols. 1-2). (Vol. 1). In Ya.Ya. Sokolov (Ed.). Moscow : Mysl [in Russian].

Dmitryuk, N., \& Balyasnikova, O. (2020). On Studying Actual Language Consciousness in Social and Regional Perspectives. In L.A. Nefedova (Ed.), The European Proceedings of Social and Behavioural Sciences (EpSBS): X International Conference "Word, Utterance, Text: Cognitive, Pragmatic and Cultural Aspects" (WUT 2020) (Chelyabinsk, April 27-29, 2020), (pp. 69-73). Chelyabinsk : Chelyabinsk State University. https://doi.org/10.15405/epsbs.2020.08.9

Dmitryuk, N.V. (1978). Kazahsko-russkij associativnyj slovar [Kazakh-Russian Associative Dictionary]. Retrieved from http://dmitryuk-nv.livejournal.com [in Russian and Kazakh].

Dmitryuk, N.V. (2012). Yazykovoe soznanie : lingvokulturologicheskie issledovaniya [Linguistic Consciousness : Linguistic and Cultural Studies]. Saarbrücken : Palmarium Academic Publishing [in Russian]. 
Dmitryuk, N.V., Artykbaeva, F.I., \& Cherkasova, G.A. (2016). Etnomentalnyj fenomen yadra yazykovogo soznaniya: associativnye issledovaniya v Kazahstane [Ethno-Mental Phenomenon of the Core of Linguistic Consciousness: Associative Researches in Kazakhstan]. Voprosy psiholingvistiki - Journal of Psycholinguistics, 2(28), 132-150 [in Russian].

Dmitryuk, N.V., Moldalieva, D.A., et al. (2014). Kazahsko-russkij associativnyj slovar [Kazakh Associative Dictionary]. Almaty-Moscow : Media-LogoS [in Russian and Kazakh].

Gerganov, E. (1984). Bolgarski normi na slovesni associacii [A Dictionary of the Associative Norms of the Bulgarian Language]. Sofija [in Bulgarian].

Gizdatov, G.G. (1997). Kognitivnye modeli v rechevoj deyatelnosti [Cognitive Models in Speech Activity]. Almaty : Gylym [in Russian].

Goroshko, E.I. (2001). Integrativnaya model svobodnogo associativnogo eksperimenta [Integrative Model of Free Associative Experiment]. Kharkiv; Moscow : Karavella [in Russian].

Humboldt, W. von. (1984). Izbrannye trudy po yazykoznaniyu [Selected Works on Linguistics]. In G.V. Ramishvili (Transl.). Moscow : Progress [in Russian].

Hume, D. (1998). Traktat o chelovecheskoj prirode [Treatise on Human Nature]. Mn : OOO "Potpurri" [in Russian].

Izbasarov, D., Islamova, E.A., Bolgarova, R.M., \& Zholshayeva, M.S. (2017). The Associative Field of the Lexemes "Work" in Russian and Tatar Language Consciousness. Revista Publicando, 4(13), 507-516.

Jung, C.G. (1919). Studies in World-Association. New-York.

Kent, G.H., \& Rosanoff, A.J. (2006). A Study of Association in Insanity. American Journal of Psychiatry. Retrieved from https://ajp.psychiatryonline.org/doi/ abs/10.1176/ajp.67.2.317 https://doi.org/10.1176/ajp.67.2.317

Kharchenko, E.V. (2003). Modeli rechevogo povedeniya v professionalnom obshchenii [Models of Verbal Behavior in Professional Dialogue]. Chelyabinsk : Izd-vo JuUrGU [in Russian].

Kharchenko, N.V. (2017). Listening in the Paradigm of Activity Psycholinguistics. Science and Education a New Dimension, 25(147), 37-41. https://doi. org/10.31174/SEND-HS2017-147V25-09

Kheirzadeh, S., \& Hajiabed, M. (2016). Differential Language Functioning of Monolinguals and Bilinguals on Positive-Negative Emotional Expression. Journal of Psycholinguistic Research, 45, 55-69. https://doi.org/10.1007/s10936014-9326-2

Kiss, G.R., Armstrong, G., \& Milroy, R. (1972). An Associative Thesaurus of English. Edinburgh : Medical Research Council.

Kopylenko, M.M. (1995). Osnovy etnolingvistiki [Fundamentals of Ethnolinguistics]. Almaty: Eurasia [in Russian].

Leontiev, A.A. (1977). Slovar associativnyh norm russkogo yazyka [Dictionary of Associative Norms of the Russian Language]. Moscow : Moscow State University [in Russian].

Leontiev, A.A. (1993). Yazykovoe soznanie i obraz mira [Language Consciousness and Image of the World]. In E.F. Tarfsov (Ed.), Yazyk $i$ soznanie : paradoksalnaya racionalnost - Language and Consciousness: The Paradoxical Rationality (pp. 16-21) Moscow : Institut yazykoznaniya RAN [in Russian].

Locke, J. (1985). Sochinenija [Works]. (Vols. 1-3). Moscow : Mysl [in Russian]. 
Lubimova, S. (2020). Associative Experiment in Studying the Sociocultural Stereotype. Kalb Studijos. Kauno Technologijos Universitetas, 36, 85-96. https://doi. org/10.5755/j01.sal.0.36.23814

Luria, A.R. (2013). Osnovy nejropsihologii [Fundamentals of Neuropsychology]. (8nd. ed.). Moscow : Izdatelskij centr "Akademija" [in Russian].

Martinek, S. (2007). Ukhainsrii associativnyj slovnik [Ukrainian Associative Dictionary]. (Vols. 1-2), (Vol. 1). Lvov : National University named after Ivan Franko [in Ukrainian].

Martinek, S. (2008). Ukhainsrii associativnyj slovnik [Ukrainian Associative Dictionary]. (Vols. 1-2), (Vol. 2). Lvov : National University named after Ivan Franko [in Ukrainian].

Mukhametzyanova, L., \& Shayakhmetova, L. (2014). Application of Associative Experiment in Forming the Foreign Communicative Competence. English Language Teaching, 7(12), 60-64. https://doi.org/10.5539/elt.v7n12p60

Ovchinnikova, I.G., Beresneva, N.I., Dubrovskaya, L.A., et al. (2000). Leksikon mladshego shkolnika (harakteristika leksicheskogo komponenta yazykovoj kompetencii) [Lexicon Junior Student (Characteristic Lexical Component of Language Competence)]. Perm : Publ. Perm State University [in Russian].

Postman, L. (1970). Norms of Word Association. New York : Academic Press.

Potebnya, A.A. (1999). Mysl $i$ yazyk [Thought and Language]. Moscow : Labirint [in Russian].

Raible, W. (2003). Language and Consciousness. In F.C. Erba, Proceedings of the International Symposium "Exploring Consciousness. Humanities, Natural Science, Religion” (pp. 17-34). Milano : Fondazione Carlo Erba.

Rosenzweig, M.R. (1961). Comparisons Among Word-Association Responses in English, French, German, and Italian. American Journal of Psychology, 74(3), 347-360. https://doi.org/10.2307/1419741

Russell, W.A., \& Jenkins, J.J. (1954). The complete Minnesota norms for Responses to 100 Words from the Kent-Rosanoff Word Association Test. Minneapolis : Dept. of Psychology, University of Minnesota.

Russell, W.A., \& Jenkins, J.J. (1954). The Complete Minnesota norms for Responses to 100 Words from the Kent-Rosanoff Word Association Test. Minneapolis: Univ. Minnesota.

Sharifian, F. (2017). Cultural Linguistics and Linguistic Relativity. Language Sciences, 59, 83-92. https://doi.org/10.1016/j.langsci.2016.06.002

Sokolova, T.V. (1999). Associativnyj tezaurus rebenka 3-6 let [Associative Thesaurus of a Child 3-6 years]. Extended abstract of Doctor's thesis. Moscow [in Russian].

Spinoza, B. (1957). Izbrannye proizvedenija [Selected works]. (Vols. 1-2). Moscow : Mysl [in Russian]. Moscow : Politicheskaja literatura [in Russian].

Tarasov, E.F. (1996). Mezhkulturnoe obshchenie - novaya ontologiya analiza yazykovogo soznaniya [Intercultural Communication - a New Ontology Analysis of Linguistic Consciousness]. Etnokulturnaya specifika yazykovogo soznaniya Ethnocultural Specificity of Linguistic Consciousness (pp. 7-22). Moscow : IYa RAS [in Russian].

Tarasov, E.F. (1998). K postroeniyu teorii mezhkulturnogo obshcheniya [On the Construction of Intercultural Communication Theory]. Yazykovoe soznanie : formirovanie $i$ funkcionirovanie - Language Consciousness : Formation and Functioning (pp. 30-35). Moscow : IYa RAS [in Russian]. 
Titova, L.N. (1975). Kyrgizsko-russkij associativnyj slovar [Kyrgyz-Russian Associative Dictionary]. Frunze : Mektep [in Russian and Kyrgyz].

Tsitova, A.I. (1981). Asacijanyunyi slounik belaruskai movi [Associative Dictionary of the Belarusian Language]. Minsk : BDU [in Belarusian].

Ufimtseva, N.V. (2000). Yazykovoe soznanie i obraz mira slavyan [Linguistic Consciousness and the Image of the World of the Slavs]. Yazykovoe soznanie $i$ obraz mira - Language Consciousness and the Image of the World (pp. 207219). Moscow : IYa RAS [in Russian].

Ufimtseva, N.V. (2020). Associative-Verbal Network as a Model of the Linguistics Picture of the World. In L.A. Nefedova (Ed.), The European Proceedings of Social and Behavioural Sciences (EpSBS): X International Conference "Word, Utterance, Text: Cognitive, Pragmatic and Cultural Aspects" (WUT 2020) (Chelyabinsk, April 27-29, 2020), (pp. 1460-1465). Chelyabinsk : Chelyabinsk State University. https://doi.org/10.15405/epsbs.2020.08.169

Ufimtseva, N.V., \& Balyasnikova, O.V. (2019). Yazykovaya kartina mira i associativnaya leksikografiya [Language Picture of the World and Associative Lexicography]. Vestnik Volgogradskogo gosudarstvennogo universiteta. Yazykoznanie - Science Journal of Volgograd State University. Linguistics, 18(1), 6-22. https://doi.org/10.15688/jvolsu2.2019.1.1 [in Russian].

Ulyanov, Yu. (1988). Latyshsko-russkii associativnyj slovar [Latin and Latin-Ruthenian Associative Dictionary]. Riga : Zinatne [in Latin].

Vygotsky, L.S. (1999). Myshlenie i rech [Thinking and Speech]. Moscow : Labyrinth [in Russian].

Zalevskaya, A.A. (1971). Svobodnye associacii v trekh yazykah [Free Associations in Three Languages]. Semanticheskaya struktura slova: psiholingvisticheskie issledovaniya - Semantic Structure of the Word: Psycholinguistic Research (pp. 178-194). Moscow [in Russian].

Zalevskaya, A.A. (1980). Psiholingvisticheskoe issledovanie principov organizacii leksikona cheloveka (na materiale mezhyazykovogo sopostavleniya rezultatov associativnyh eksperimentov) [Psycholinguistic Research Organization Principles of Human Vocabulary (based on cross-language comparison of the results of associative experiment)]. Extended abstract of Doctor's thesis. Leningrad [in Russian].

Zalevskaya, A.A. (2007). Vvedenie $v$ psiholingvistiku [Introduction to Psycholinguistics]. (2nd. ed.). Moscow: Russian State Humanitarian University [in Russian].

\section{АННОТАЦИЯ}

Вступление. Ассоциативные исследования широко практикуются в области смежных с лингвистикой наук как междисциплинарный подход к изучению взаимосвязи языка с сознанием, психикой и культурой человека. Созданный нами корпус ассоциативных данных на казахском языке пополняет ассоциативную лексикографию в контексте широких межкультурных сопоставлений.

материалы и методы. Словари ассоциативных норм казахского языка (Dmitryuk, 1978; Dmitryuk, Moldalieva et al., 2014), подготовленные на основе данных свободных ассоциативных экспериментов (САЭ) с 1000 студентами- 
казахами, содержат уникальные сведения о ментальности и этнокультурных особенностях казахского этноса в советский и современный период. САЭ широко известный в международной практике метод использования ассоциативных данных как один из достоверных способов доступа к языковому сознанию человека. Статистическая обработка всего корпуса полученных ассоциаций позволила представить для аналитического сопоставления иерархию базовых ценностей казахов в виде ядра языкового сознания - его центральных и периферийных зон - в советский и постсоветский периоды.

Результаты. В ходе диахронического внутриэтнического сопоставительного анализа было обнаружено, что существенным изменениям подверглись такие базовые ценности казахов, как отношение к религии, свободе, суверенитету, к государственной символике; традиционно неизменными остались этнокультурные стержневые ценностные предпочтения, составляющие сущность специфики национального менталитета этноса: отношение к родине и к матери, к старшим, к мужчине, гендерные и возрастные особенности в иерархии семейно-родственных отношений.

Выводы. Внутриязыковое сопоставление содержания данных словарей выявило устойчивый корпус неизменяемых ценностных приоритетов, свидетельствующих о достаточно прочном стержне и значительной степени витальности казахского социума. Работа вносит вклад в область межкультурных ассоциативных исследований, ассоциативной лексикографии, способствует развитию перспективных исследований в казахстанской психолингвистике.

Ключевые слова: казахские ассочиативные словари, ядро языкового сознания, базовые ценности.

\section{Дмитрюк Наталія \& Абрамова Галина. Асоціативні словники як етноментальний феномен: базові цінності в ядрі мовної свідомості етносу}

\section{АНОТАЦІЯ}

Вступ. Асоціативні дослідження широко практикуються в галузі суміжних з лінгвістикою наук як міждисциплінарний підхід до вивчення взаємозв'язку мови з свідомістю, психікою і культурою людини. Створений нами корпус асоціативних даних казахською мовою поповнює асоціативну лексикографію в контексті широких міжкультурних зіставлень.

матеріали та методи. Словники асоціативних норм казахської мови (Dmitryuk, 1978; Dmitryuk, Moldalieva et al., 2014), підготовлені на основі даних вільних асоціативних експериментів (ВАE) 31000 студентами-казахами, містять унікальні відомості про ментальність і етнокультурні особливості казахського етносу в радянський і сучасний період. ВАЕ - широко відомий у міжнародній практиці метод використання асоціативних даних як один із достовірних способів доступу до мовної свідомості людини. Статистична обробка всього корпусу отриманих асоціацій дозволила представити для 
аналітичного зіставлення ієрархію базових цінностей казахів у вигляді ядра мовної свідомості - його центральних і периферійних зон - у радянський $і$ пострадянський періоди.

Результати. У ході діахронічного внутрішньо-етнічного порівняльного аналізу було виявлено, що суттєвих змін зазнали такі базові цінності казахів як відношення до релігії, свободи, суверенітету, до державної символіки; традиційно незмінними залишилися етнокультурні стрижневі ціннісні переваги, які становлять сутність специфіки національного менталітету етносу: ставлення до батьківщини і до матері, до старших, до чоловіка, гендерні та вікові особливості в ієрархії сімейно-родинних відносин.

Висновки. Внутрішньо-мовленнєві зіставлення змісту даних словників виявили стійкий корпус незмінних ціннісних пріоритетів, які свідчать про досить міцний стрижень і значну міру вітальності казахського соціуму. Робота вносить вклад в галузь міжкультурних асоціативних досліджень, асоціативної лексикографії, сприяє розвитку перспективних досліджень у казахській психолінгвістиці.

Ключові слова: казахські асоціативні словники, ядро мовної свідомості, базові цінності. 